EMPOWER : Jurnal Pengembangan Masyarakat Islam

Vol. 5, No.1, Juni 2020, hlm. 118-132

e-ISSN : 2580-0973, p-ISSN : 2580-085X

Tersedia Online di : http://syekhnurjati.ac.id/jurnal/index.php/empower

Email : empowerjurnal@gmail.com

\title{
Dampak Pergeseran Tenaga Kerja Tambak Garam di Kabupaten Cirebon
}

\author{
Ria Adriyani* \\ (Administrasi Publik, Fakultas Ilmu Sosial dan Ilmu Politik Universitas 17 Agustus \\ 1945 Cirebon) \\ Email: ria.adriyani@gmail.com,
}

\section{Agus Siswanto**}

(Program Studi Teknik Elektro, Fakultas Teknik, Universitas 17 Agustus 1945

Cirebon)

E-mail: asiswanto.untagcrb@gmail.com,

\section{Yuliana Saryip $\mathbf{W}^{* * *}$}

(Program Studi Ilmu Hukum, fakultas Hukum, Universitas 17 Agustus 1945

Cirebon)

E-mail: yulianawijayanti85@gmail.com,

\section{Nurhannah Widianti****}

(Program Studi Bimbingan Konseling Islam, Fakultas Ushuluddin Adab dan

Dakwah, IAIN Syekh Nurjati Cirebon)

E-mail: nurhanahw@gmail.com,

\section{Sacandra Aji Rivaldi*****}

(Program Studi Komunikasi Penyiaran Islam, Fakultas Ushuluddin Adab dan Dakwah, IAIN Syekh Nurjati Cirebon)

E-mail: Sacandraaji@yahoo.com

\section{Article History}

Submitted: 14.06.2020; Revised: 22.06.2020; Accepted: 22.06.2020;

\begin{abstract}
The purpose of this study, namely (1) to describes the causes of the local workforce of the affected areas unable to enter the industrial sector; (2) describe the role of government, and industry in anticipating the emergence of unemployment in industrial affected areas. The research
\end{abstract}


method used is a qualitative method with a population of 519 people who originally worked on salt land. Meanwhile, the sample data sources were selected purposively with a sample of 100 people determined through Slovin formula. The data collection technique of this study uses triangulation: interviews, observation, and documentation studies. The results of the study showed: (1) former salt farmers as local laborers did not have adequate administrative, technical, and technological skills that were difficult to absorb in the industrial sector; (2) the government and industry need to build industrial estates that are friendly to local labor. Skills that are skilled and capable of mastering technology in the power generation industry must also be prepared. Its implementation, that is, can be through the establishment of vocational schools that are in accordance with industry needs.

Keywords: Industrial Impact, Shift in Labor, Salt Ponds.

\begin{abstract}
Abstrak
Tujuan penelitian ini, yaitu (1) mendeskripsikan penyebab tenaga kerja lokal daerah terdampak tidak bisa masuk ke sektor industri; (2) mendekripsikan peranan pemerintah, dan industri dalam mengantisipasi munculnya pengangguran di daerah terdampak industri. Metode penelitian yang digunakan adalah metode kualitatif dengan populasi penelitian sebanyak 519 warga yang semula menggarap lahan garam. Sementara itu, sampel sumber data dipilih secara purposive dengan jumlah sampel 100 orang yang ditentukan melalui rumus Slovin. Teknik pengumpulan data penelitian ini menggunakan triangulasi: wawancara, observasi, dan studi dokumentasi. Hasil penelitian menunjukkan: (1) para eks petani garam sebagai tenaga kerja lokal ternyata tidak memiliki keterampilan administrasi, teknis, dan teknologi yang memadai sehingga sulit diserap di sektor industri; (2) pemerintah dan industri perlu membangun kawasan industri yang ramah terhadap tenaga kerja lokal. Sumber daya manusia yang terampil dan mampu menguasai teknologi dalam industri pembangkit listrik pun harus dipersiapkan. Pengimplementasiannya, yaitu bisa melalui pendirian vokasi yang sesuai dengan kebutuhan industri.
\end{abstract}

Kata Kunci: Dampak Industri, Pergeseran Tenaga Kerja, Tambak Garam. 


\section{PENDAHULUAN}

Masyarakat kawasan Pesisir Pantai Utara, khususnya wilayah Cirebon Timur secara turun-temurun berprofesi sebagai petani garam. Tambak garam di daerah tersebut menempati lahan yang produktif, yakni berlokasi di pesisir pantai. Namun, sekarang sebagian lokasi strategis itu mulai mengalami alih fungsi. Semula kawasan tersebut merupakan lahan produktif garapan petani garam, tetapi kini berubah menjadi kawasan industri. Hal ini salah satunya karena adanya Kebijakan Industri Nasional (KIN).

KIN merupakan arah dan tindakan untuk melaksanakan Rencana Induk Pembangunan Industri Nasional yang memiliki fokus pada perkembangan Industri Pembangkit Listrik. Industri tersebut sangat membutuhkan lahan yang luas sehingga mengakibatkan adanya pengalihan lahan masyarakat di sepanjang Pesisir Pantai Cirebon Timur.

Adanya peralihan fungsi tersebut diharapkan mampu mengurangi angka pengangguran dan mampu menyerap tenaga kerja lokal, khususnya daerah yang terkena dampak. Dalam makna lain, pengembangan kawasan industri sebenarnya bisa menjadi salah satu solusi bagi penanganan masalah tenaga kerja. Hal ini selaras dengan pendapat Nur adanya industri mengakibatkan tenaga kerja banyak terserap, baik secara langsung maupun tidak langsung ${ }^{1}$.

Terkait dengan hal itu, pemerintah dengan instansi terkait berkewajiban merumuskan kebijakan sektor industri yang menunjang pembangunan ekonomi masyarakat terdampak. Di sisi lain, pengusaha industri pun berkewajiban untuk melaksanakan proses industrialisasi dengan meminimalisir risiko terhadap keadaan masyarakat yang terkena dampak industri.

${ }^{1}$ Djakaria M. Nur, 'Dampak Pembangunan Kawasan Industri Di Kabupaten Bekasi Terhadap Alih Fungsi Lahan Dan Mata Pencaharian Penduduk', Jurnal GEA, 7.2 (2012), pp. 1-10. 
Akan tetapi, realitas menunjukkan hal sebaliknya. Masalah itulah yang dibahas dalam penelitian ini, yaitu tentang pengembangan industri di Pesisir Cirebon Timur yang membuat masyarakat petani garam di kawasan industri kehilangan mata pencahariannya. Kesempatan kerja pun semakin sempit, pendapatan masyarakat berkurang, dan daya serap tenaga kerja yang bersumber dari daerah terdampak sangat minim. Hal ini tentu berpotensi menambah ironis kehidupan masyarakat di daerah pesisir yang menurut Satria problem itu berupa kemiskinan, ketertinggalan, ketertindasan, dan keterasingan².

Berdasarkan hal di atas, maka penurunan pangsa tenaga kerja sektor primer harus dibarengi secara proporsional oleh penurunan persentase tenaga kerja di sektor sekunder dan tersier. Pembangunan industri harus diarahkan untuk mampu mendistribusikan tenaga kerja dari sektor tambak garam sesuai dengan pangsa pasar sehingga risiko kehilangan pendapatan dari petani garam dapat dikurangi.

Dalam upaya berkelanjutan maka standar IFC Performance Standard on Environmental and Social Sustainability 3 dan Equator Principle 4 dapat menjadi acuan untuk meminimilisir dampak yang diakibatkan oleh pembangunan industri pembangkit listrik. Terkait dengan hilangnya sumber daya penghidupan masyarakat petani garam, Performance Standard 5 dari IFC Performance Standard on Environmental and Social Sustainability mewajibkan pihak peminjam yang terlibat dalam skema pembiayaan proyek multilateral untuk melaksanakan program pemulihan terlebih lagi apabila proyek pembangunan tersebut telah menyebabkan terjadinya atau hilangnya sumber mata pencaharian masyarakat (Rencana Program Pengembangan dan Pengembangan Usaha Mikro pada Masyarakat, 2017)3.

Berkenaan dengan itu, penelitian terkait dampak industri perlu dilakukan dengan tujuan mendeskripsikan hal yang menyebabkan tenaga kerja lokal daerah terdampak tidak bisa masuk ke sektor industri dan mendekripsikan peranan yang dapat dilakukan

\footnotetext{
${ }^{2}$ Arif Satria, Pengantar Sosiologi Masyarakat Pesisir (Jakarta: Obor, 2015), p. 126.

3 Rencana Program Pengembangan dan Pengembangan Usaha Mikro pada Masyarakat. (Jakarta, 2017)
} 
pemerintah maupun industri dalam mengantisipasi munculnya pengangguran di daerah terdampak industry.

Pembangunan industri di suatu kawasan idealnya dapat memberikan lapangan kerja baru bagi masyarakat sekitar. Hal ini diperkuat oleh pendapat Saefullah bahwa hendaknya perluasan industri mampu meningkatkan kualitas kehidupan masyarakat ${ }^{4}$. Dalam hal ini, jangan sampai modernisasi industri membuat penduduk kehilangan tempat tinggal dan sumber pencaharian yang menjadikan kualitas sumber daya manusia menurun.

Terkait dengan hal itu, pemerintah turut andil dalam memonitoring berbagai kebijakan agar pengembangan industri tidak menggeser fasilitas pendidikan maupun sosial yang justru diperlukan untuk meningkatkan kualitas sumber daya manusia. Penelitian sebelumnya yang relevan menunjukkan bahwa pemerintah terkait perlu melakukan pengendalian konversi lahan pertanian ke non pertanian di wilayah Kecamatan Pamanukan. Konversi lahan yang terus-menerus terjadi merupakan ancaman terhadap keberlangsungan kegiatan pertanian masyarakat yang merupakan sektor penghidupan utama bagi mereka. Pemerintah harus menjaga keberlangsungan kegiatan pertanian bagi rumah tangga pertanian tersebut ${ }^{5}$.

Pemberdayaan bagi masyarakat terdampak industri pun perlu dilakukan. Dalam konteks ini, Ria, Nurhannah, Erna dan Agus menyatakan bahwa pemberdayaan sosial masyarakat pesisir penting untuk direalisasikan sebab itu merupakan upaya megubah perilaku ekonomi, orientasi pendidikan, dan sosial budaya setempat agar lebih baik serta demi

${ }^{4}$ D. Saefullah, Pemikiran Kontemporer Administrasi Publik (Perspektif Manajemen Sumber Daya Manusia Dalam Era Desentralisasi, Laboraturium Pengkajian Penelitian, Dan Pengembangan Administrasi Negara (Bandung: LP3AN FISIP UNPAD, 2007), p. 177.

${ }^{5}$ Linda D. Rohmadiani, ‘Dampak Konservasi Lahan Pertanian Terhadap Kondisi Sosial Ekonomi Petani (Studi Kasus: Jalur Pantura Kecamatan Pamanukan Kabupaten Subang)', Jurnal Teknik Waktu, 9.2 (2017), pp. 71-81. 
mengatasi kemiskinan ${ }^{6}$. Hal ini selaras dengan pernyataan Slamet bahwa pemberdayaan sangat dibutuhkan agar masyarakat mampu membangun dirinya sendiri, yakni berdaya, paham, termotivasi, memiliki kesempatan, mampu melihat dan memanfaatkan peluang, bersinergi, mampu bekerjasama, serta mampu bertindak sesuai inisiatif ${ }^{7}$.

Setiap pembangunan akan berpotensi menimbulkan berbagai dampak positif maupun negatif. Hal ini selaras dengan pendapat Hidayat, Ahyar, dan Meti bahwa adanya industri berdampak pada aspek produksi, sosial, ekonomi maupun lingkungan kepada petani dan masyarakat di sekitar kawasan ${ }^{8}$. Idealnya, dampak positif harus lebih mendominasi dari dampak negatif, sehingga dapat dikatakan pembangunan tersebut dapat memberikan manfaat khususnya kepada masyarakat sekitar proyek pembangunan.

Akan tetapi, implementasinya tentu akan menghadapi beberapa tantangan. Siagian menjelaskan bahwa ada tiga faktor utama penyebab proses pembangunan ekonomi atau industri tidak berlangsung sesuai harapan'. Faktor tersebut, antara lain (1) adanya sikap menolak perubahan dari masyarakat; (2) adanya kecenderungan untuk "meloncat" dari masyarakat pertanian ke masyarakat industri tanpa didukung oleh pengetahuan, keterampilan, infrastruktur dan sarana yang mutlak diperlukan; (3) kurangnya pengertian di kalangan masyarkat termasuk dalam lingkungan birokrasi pemerintah tentang pentingnya "human investment" dalam proses pembangunan. Kenyataan tersebut terbukti dari rendahnya anggaran dan belanja negara yang diperuntukkan bagi

\footnotetext{
${ }^{6}$ Ria A and others, 'Pemanfaatan Olahan Ikan Dan Rajungan Sebagai Income Generic Bagi Masyarakat Mundu Pesisir Kabupaten Cirebon', Seminar Nasional Pengabdian Kepada Masyarakat (PKM), 1.1 (2018), pp. 865-881.

7 Oos M Anwas, Pemberdayaan Masyarakat Di Era Global (Bandung: ALFABETA, 2014).

8 Y. Hidayat, Ahyar I, and Meti E, ‘Dampak Konversi Lahan Pertanian Terhadap Ekonomi Rumah Tangga Petani Padi (Studi Kasus Kecamatan Kertajati Kabupaten Majalengka Jawa Barat)', Jurnal Pengkajian Dan Pengembangan Teknologi Pertanian, 20.2 (2017), pp. 171-82.

9 Sondang P. Siagian, Administrasi Pembangunan Konsep, Dimensi, Dan Strategisnya (Jakarta: Bumi Aksara, 2007), pp. 87-88.
} 
pendidikan dan pelatihan. Padahal hanya dengan investasi manusia yang memadailah tenaga kerja yang kapabel dan terampil dapat disiapkan untuk mengelola dan menyelenggarakan seluruh kegiatan pembangunan.

Metode yang digunakan dalam penelitian ini adalah metode kualitatif. Menurut Sugiyono metode kualitatif bertujuan untuk mendeskripsikan dan menganalisis fenomena, peristiwa, aktifitas sosial, sikap kepercayaan, persepsi, pemikiran orang secara individual maupun kelompok ${ }^{10}$.

Populasi dalam penelitian ini adalah 519 warga yang semula menggarap lahan garam. Sementara itu, sampel sumber data dipilih secara purposive dan pengambilan sampel dilakukan dengan menggunakan rumus Slovin karena keterbatasan tenaga, waktu dan biaya ${ }^{11}$. Dari hasil perhitungan, maka jumlah sampel dalam penelitian ini sebanyak 100 orang.

Instrumen dalam penelitian ini adalah peneliti karena dalam penelitian kualitatif, instrumen utama adalah peneliti itu sendiri. Sementara itu, data yang diperoleh dari lapangan adalah data primer yang diperoleh langsung ketika turun ke lapangan dan juga data pendukung diperoleh dari dokumen laporan pelaksanaan serta lainnya. Terkait dengan hal itu, teknik pengumpulan data pada penelitian ini menggunakan triangulasi data dengan rincian sebagai berikut.

1. Pelaksanaan wawancara bersumber dari pedoman wawancara tidak terstruktur (bersifat non directive) maupun terstruktur (bersifat directive). Untuk memperoleh informasi tentang keberadaan petani garam yang berada di kawasan industri, maka peneliti mewawancarai (a) Kepala Desa di Desa Kanci, Astanajapura, Astana Mukti, dan Waruduwur), (b) tokoh masyarakat; (c) kelompok masyarakat petani garam. Selanjutnya, untuk mendapatkan informasi tentang kawasan industri, peneliti mewawancarai pengusaha industri pembangkit listrik dan aparat pemerintah yang terkait dengan pengoperasian kawasan industri.

\footnotetext{
10 Sugiyono, Memahami Penelitian Kualitatif (Bandung: Alfabeta, 2007), p. 1.

11 Sugiyono, Metode Penelitian (Bandung: Alfabeta, 2009), p. 81.
} 
2. Penelitian ini memakai observasi partisipasi diharapkan peneliti dapat memperoleh data yang tidak terjangkau oleh teknik wawancara sehingga memperoleh informasi yang betul-betul diperlukan.

3. Studi dokumentasi digunakan untuk melengkapi dari penggunaan metode observasi dan wawancara. Bentuknya adalah berupa catatan peristiwa yang sudah berlalu, bisa berbentuk tulisan, atau berupa peraturan-peraturan.

Adapun teknik analisis data yang digunakan dalam penelitian ini berdasarkan konsep Miles dan Huberman. Miles dan Huberman bahwa aktifitas dalam analisis data dilakukan secara interaktif dan berlangsung secara terus menerus sampai tuntas sehingga datanya sudah jenuh ${ }^{12}$. Langkah-langkah analisis data mencakup tiga hal, yakni data reduction, data display, dan conclusion drawing/verivication.

\section{HASIL DAN PEMBAHASAN}

Otonomi daerah memberikan kewenangan kepada setiap daerah untuk mengembangkan potensinya masing-masing. Adanya kebijakan tersebut membuka kesempatan bagi pemerintah setempat untuk membangun kawasan industri. Namun, pemerintah daerah ketika akan mengubah daerahnya menjadi kawasan industri harus memperhatikan berbagai aspek. Seyogyanya pembangunan yang dilakukan harus memberikan manfaat bagi masyarakat baik dari segi ekonomi, pendidikan, pekerjaan, dan mampu meningkatkan taraf hidup masyarakat setempat, khususnya masyarakat yang secara langsung terkena dampak perubahan kawasan industri.

Adapun kawasan Cirebon Timur sebagai daerah pesisir pantai dengan kehidupan masyarakat yang heterogen menjadi magnet bagi perkembangan sektor industri, khususnya industri pembangkit tenaga listrik. Komposisi struktur demografi penduduk di wilayah Cirebon Timur idealnya berkorelasi dengan peningkatan potensi pasar dan produktivitas

\footnotetext{
${ }^{12}$ Sugiyono, Memahami Penelitian Kualitatif.
} 
yang akan memberikan dampak pada meningkatnya kesejahteraan melalui peningkatan pendapatan perkapita. Namun, hasil analisis menunjukkan hal yang sebaliknya. Banyaknya lahan tambak garam yang digunakan untuk pembangunan dan pengembangan industri pembangkit listrik berdampak pada hilangnya lahan garam. Berkurangnya lahan tambak garam menyebabkan produksi garam menurun drastis dan cita-cita mewujudkan swasembada garam seperti dicanangkan oleh programprogram pemerintah sulit terwujud.

Salah satu penyebab utama kelangkaan tenaga kerja dari lokal, khususnya di daerah terdampak adalah kurangnya tenaga kerja yang memenuhi standar kompetensi tertentu. Hal tersebut diperoleh dari observasi yang menunjukkan bahwa pengetahuan dan pendidikan masyarakat yang tergolong tenaga kerja produktif masih minim. Tidak hanya itu, transformasi sektor industri pun tidak dibarengi dengan transformasi struktur ketenagakerjaan. Pada saat pangsa tenaga kerja sektor industri meningkat justru muncul pengangguran tenaga kerja dalam jumlah yang relatif banyak.

Hasil observasi pun menunjukkan ternyata masyarakat sebagian besar memiliki pekerjaan yang mengandalkan tenaga fisik tanpa ditunjang keahlian yang memadai. Terbatasnya tenaga kerja untuk bisa terserap pada sektor industri yang berteknologi canggih karena tidak memiliki keterampilan teknis yang bisa beradaptasi dengan perubahan drastis wilayah menjadi kawasan industri.

\section{Dimensi Tingkat Pendidikan dan Penguasaan Teknologi}

Kualitas tenaga kerja akan dipengaruhi oleh tingkat pendidikan. Hal inilah yang menjadi alasan sulitnya tenaga kerja lokal daerah terdampak industri pembangkit listrik tidak dapat masuk ke sektor industri. Asumsinya bahwa makin tinggi tingkat pendidikan, maka makin tinggi pula kualitas tenaga kerja. Hal ini selaras dengan pendapat Saefullah bahwa tingkat pendidikan yang sesuai dengan tuntutan perkembangan 
industri di wilayah terdampak sangatlah penting karena berpengaruh terhadap kesempatan masyarakat memperoleh pekerjaan, cara berpikir, daya nalar, dan keluasan pengetahuan ${ }^{13}$.

Terkait dengan itu, kondisi latar belakang pendidikan responden di kawasan industri tampak pada diaram berikut ini:

Gambar 1. Pendidikan Responden

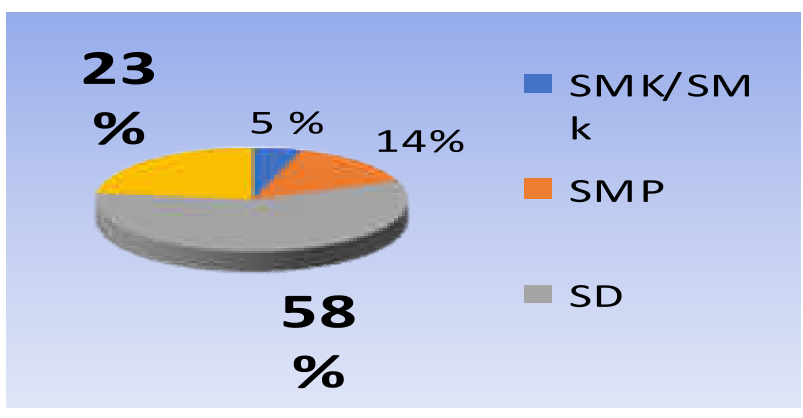

Pekerjaan responden mayoritas (78\%) sebagai petani garam. Hasil mata pencaharian tersebut dapat menghidupi keluarga, meskipun hanya sebagai tenaga kerja di tambak garam sewaan dari saudagar pemilik lahan garam (kopang) atau sebagai buruh panggul garam. Perkembangan sektor industri yang pesat ternyata tidak mampu diimbangi dengan alih profesi secara otomatis dari tenaga kerja para petani garam yang lahannya tergusur menjadi tenaga kerja industri pembangkit listrik.

Gambar 2. Aktivitas para Petani Garam

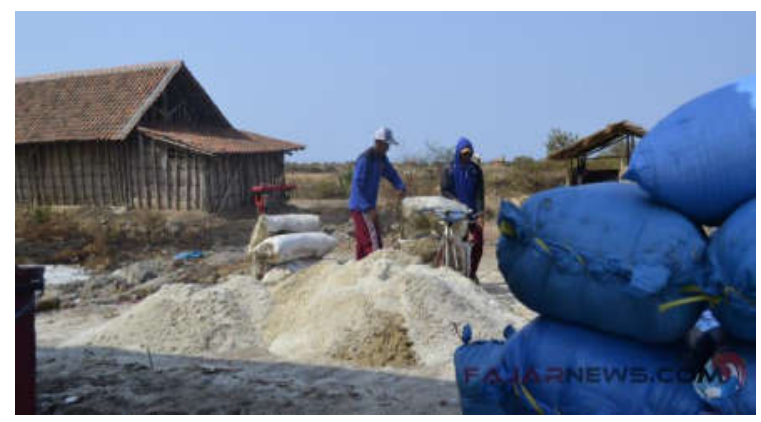

Tenaga kerja yang terampil dan memiliki keahlian merupakan syarat utama agar dapat terserap oleh industri. Oleh karena itu, untuk

\footnotetext{
${ }^{13}$ Saefullah.
} 
mendapatkan kriteria tenaga kerja yang sesuai dengan kebutuhan industri perlu didukung dengan tingkat pendidikan yang mumpuni oleh para tenaga kerja. Akan tetapi, hasil penelitian menunjukkan bahwa tingkat pendidikan di kawasan yang tedampak industri pada umumnya relatif rendah. Sebagian besar hanya memiliki pendidikan pada tingkat dasar dan menengah.

Kondisi demikian menyebabkan tenaga kerja lokal tidak mampu terserap oleh industri dengan kemampuan pendidikan dan keterampilan (vokasi) rendah. Terkait dengan hal itu, diagram berikut ini menunjukkan tingkat potensi vokasi pada responden.

Gambar 3. Potensi Vokasi

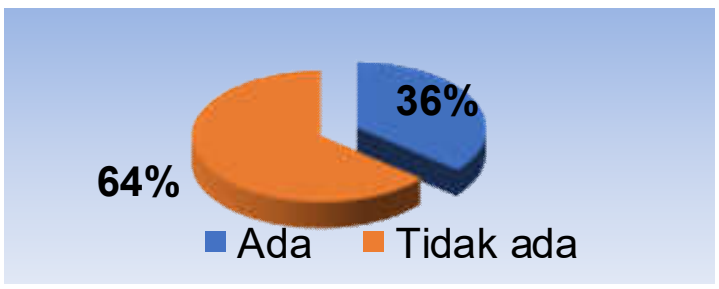

Potensi masyarakat yang memiliki peluang untuk diberikan pelatihan keterampilan atau vokasi besarnya $36 \%$. Adanya keingian masyarakat untuk vokasi tentu harus dibarengi dengan kesungguhan pemerintah dan pengusaha industri untuk menangani secara serius. Hadirnya investasi di wilayah timur berdampak pada serapan tenaga kerja. Di sisi lain, pesatnya pertumbuhan jumlah industri di kawasan Cirebon Timur seharusnya berimbas pada penyerapan tenaga kerja lokal di wilayah tersebut.

Berdasarkan hasil penelitian tampak adanya ketidaksiapan dari masyarakat maupun pihak-pihak terkait mengenai pentingnya pembangunan industri yang dimbangi pula oleh daya serap tenaga kerja dari lokal, khususnya daerah terdampak. 


\section{Peranan Pemerintah dan Industri}

Titik berat pembangunan diletakkan pada bidang ekonomi. Akan tetapi, peningkatan dan perluasan kegiatan ekonomi jangan sampai mengganggu, bahkan merusak aspek-aspek manusianya. Peningkatan produksi dan perluasan industri perlu mengintegrasikan aspek-aspek penduduk atau masyarakat dalam perencanaan dan pelaksanaan pembangunan. Pelaksanaan otonomi daerah atau desentralisasi sebagaimana diatur dalam Undang-Undang Nomor 23 Tahun 2014 tentang Pemerintahan Daerah diarahkan untuk mempercepat terwujudnya kesejahteraan masyarakat melalui peningkatan pelayanan, pemberdayaan, dan peran serta masyarakat, serta peningkatan daya saing daerah ${ }^{14}$.

Dalam kaitannya dengan sektor industri, adanya pembagian urusan pemerintahan memberi banyak peluang yang dapat dimanfaatkan oleh daerah provinsi, kabupaten, dan kota. Tujuannya, yaitu untuk mempercepat pertumbuhan dan pengembangan industri di daerah serta meminimalkan ketidakmerataan penyebaran industri di wilayah Indonesia. Sehubungan dengan itu, penggunaan tenaga kerja setempat dalam penyelenggaraan sektor industri perlu mendapat perhatian khusus. Terlebih apabila terdapat tenaga lokal yang memenuhi syarat administratif dan mutu serta perundang-undangan. Data mengenai potensi tenaga kerja lokal di Pesisir Pantai Cirebon Timur tampak pada tabel di bawah ini.

Tabel 3. Rentang Usia

\begin{tabular}{lll}
\hline USIA & JUMLAH & $\%$ \\
\hline$(0-15$ th $)$ & 17 & 17 \\
$(16-30)$ & 63 & 63 \\
$(31-60)$ & 20 & 20 \\
\hline JUMLAH & $\mathbf{1 0 0}$ & $\mathbf{1 0 0}$ \\
\hline
\end{tabular}

${ }_{14}$ Undang-Undang Nomor 23 Tentang Peraturan Daerah (Indonesia, 2014). 
Berdasarkan data usia anak-anak responden maka usia produktif cukup signifikan, mereka adalah tenaga kerja produktif yang berusia antara 16 tahun sampai dengan 30 tahun. Keberadaan mereka seharusnya bisa menjadi potensi besar untuk pembangunan masyarakat yang bergeser pada sektor industri. Kemampuan anak-anak responden ini masih bisa dikembangkan secara maksimal untuk terserap dalam dunia industri.

Mengadakan pelatihan dan keterampilan merupakan solusi yang dapat ditempuh untuk mendidik masyarakat yang berpotensi vokasi agar mandiri berbekal keterampilan teknis yang baik. Diharapkan hal ini dapat menciptakan lapangan kerja atau masyarakat bisa memperoleh pekerjaan dengan penghasilan layak. Di sisi lain, pihak-pihak terkait dapat memberikan perhatian terhadap anak-anak usia sekolah di kawasan industri dengan membantu biaya pendidikan agar mereka bisa menempuh pendidikan tinggi. Dampaknya diharapkan dapat mencetak sumber daya manusia yang jauh lebih baik dan menjadi tenaga kerja lokal profesional sesuai kebutuhan sektor industri.

Monitoring berkala terhadap ketersediaan tenaga kerja lokal yang pandai dan terampil pun perlu dilakukan agar meminimalisir tenaga kerja asing atau tenaga dari luar daerah. Dalam hal ini, pemerintah daerah memiliki peran yang penting untuk menciptakan pembangunan masyarakat daerah terdampak. Selain itu, sanksi tegas pun perlu diterapkan untuk penguasaha yang lalai terhadap pemanfaatan tenaga kerja lokal atau yang tidak memberikan kompensasi untuk pendampingan masyarakat yang kehilangan mata pencaharian.

Pergerakan industri idealnya memberi peluang kerja dan dampak turunan lain. Seperti bergeraknya sektor pendukung yang bisa dimanfaatkan masyarakat lokal. Pihak-pihak terkait pun perlu menyiapkan sumber daya manusia yang berkompeten sehingga dampak dari kehadiran investasi tersebut bisa lebih dirasakan. Wilayah Pesisir Pantai Cirebon Timur, kultur pekerjaan masyarakatnya didominasi oleh pertanian, kelautan dan juga tambak garam. Kehadiran investasi pembangkit tenaga listrik di wilayah timur, menjadi gambaran upaya yang dapat dilakukan untuk mempersiapkan sumber daya manusia yang berkualitas. 


\section{SIMPULAN}

Pengembangan kawasan industri di wilayah Pesisir Pantai Cirebon Timur berdampak terhadap pergeseran tenaga kerja para petani garam. Mereka kehilangan lahan tambak garam dan kehilangan mata pencaharian. Berdasarkan dimensi penelitian bahwa sumber daya manusia para eks petani garam sebagai tenaga kerja lokal ternyata sulit masuk ke sektor industri karena tidak memiliki tingkat Pendidikan yang dibutuhkan industri, tidak memenuhi keterampilan administrasi, teknis, dan penguasaan teknologi pun sangat minim. Oleh karena itu, pemerintah, industri, dan berbagai pihak terkait perlu melakukan komunikasi untuk membangun kawasan industri yang ramah terhadap tenaga kerja lokal dan berorientasi pembangunan. Sumber daya manusia yang berkualitas perlu dipersiapkan dengan matang agar menghasilkan tenaga kerja yang terampil dan mampu menguasai teknologi dalam industri pembangkit listrik. Solusi yang dapat ditempuh, yaitu dengan cara mendirikan vokasi atau balai latihan keterampilan yang sesuai dengan kebutuhan industri. 


\section{DAFTAR PUSTAKA}

A, Ria, Nurhannah W, Erna, and Agus S, 'Pemanfaatan Olahan Ikan Dan Rajungan Sebagai Income Generic Bagi Masyarakat Mundu Pesisir Kabupaten Cirebon', Seminar Nasional Pengabdian Kepada Masyarakat (PKM), 1.1 (2018), 865-81

Anwas, Oos M, Pemberdayaan Masyarakat Di Era Global (Bandung: ALFABETA, 2014)

Hidayat, Y., Ahyar I, and Meti E, 'Dampak Konversi Lahan Pertanian Terhadap Ekonomi Rumah Tangga Petani Padi (Studi Kasus Kecamatan Kertajati Kabupaten Majalengka Jawa Barat)', Jurnal Pengkajian Dan Pengembangan Teknologi Pertanian, 20.2 (2017), 171-82

Nur, Djakaria M., 'Dampak Pembangunan Kawasan Industri Di Kabupaten Bekasi Terhadap Alih Fungsi Lahan Dan Mata Pencaharian Penduduk', Jurnal GEA, 7.2 (2012), 1-10

Rohmadiani, Linda D., 'Dampak Konservasi Lahan Pertanian Terhadap Kondisi Sosial Ekonomi Petani (Studi Kasus: Jalur Pantura Kecamatan Pamanukan Kabupaten Subang)', Jurnal Teknik Waktu, 9.2 (2017), 71-81

Saefullah, D., Pemikiran Kontemporer Administrasi Publik (Perspektif Manajemen Sumber Daya Manusia Dalam Era Desentralisasi, Laboraturium Pengkajian Penelitian, Dan Pengembangan Administrasi Negara (Bandung: LP3AN FISIP UNPAD, 2007)

Satria, Arif, Pengantar Sosiologi Masyarakat Pesisir (Jakarta: Obor, 2015)

Siagian, Sondang P., Administrasi Pembangunan Konsep, Dimensi, Dan Strategisnya (Jakarta: Bumi Aksara, 2007)

Sugiyono, Memahami Penelitian Kualitatif (Bandung: Alfabeta, 2007)

- - , Metode Penelitian (Bandung: Alfabeta, 2009)

Undang-Undang Nomor 23 Tentang Peraturan Daerah (Indonesia, 2014) 